\title{
Is autotoxicity responsible for inhibition growth of new conspecific seedlings under the canopy of the invasive Acacia dealbata Link?
}

\section{¿Es la autotoxicidad responsable de la inhibición del crecimiento de nuevas plántulas conespecíficas bajo el dosel de la invasora Acacia dealbata Link?}

\author{
Narciso AguileraA ${ }^{1,2 *}$, Lubia M. Guedes², José Becerra² \& Luis GonzÁlez ${ }^{3}$ \\ 1'Departamento de Silvicultura, Facultad de Ciencias Forestales, Universidad de Concepción, Casilla 160-C, Concepción, \\ Chile. \\ ${ }^{2}$ Laboratorio de Química de Productos Naturales, Departamento de Botánica, Facultad de Ciencias Naturales y Oceanográficas, \\ Universidad de Concepción, Casilla 160-C, Concepción, Chile. \\ ${ }^{3}$ Departamento Bioloxía Vexetal e Ciencia do Solo, Facultade de Biología, Universidad de Vigo, As Lagoas Marcosende 36310 \\ Vigo, España. \\ *naguileramarin@gmail.com
}

\begin{abstract}
Autotoxicity is a particular form of allelopathy and is suspected to be responsible for regulating intraspecific competition under the Acacia dealbata Link (Fabaceae) canopy. Was established a bioassay with controlled conditions following the natural patterns of plant material accumulation under the $A$. dealbata canopy to determine the effects of chemical compounds released by leaves, bark, flowers and pods of the invasive species on germination and early growth of conspecific seedlings. Morphological changes caused by $A$. dealbata plant parts in roots of $A$. dealbata seedlings grown in natural and controlled conditions were evaluated with scanning electron microscopy. The composition and behavior of the phytotoxicity of litter under the A. dealbata canopy throughout its phenological cycle were studied. The main chemical compounds in the soil under the canopy were identified. Most of the tested plant parts inhibited the germination and early seedling growth, prevented the root hair formation, destroyed the rhizodermis and altered the parenchyma tissue of radicles. The pods caused the greatest autotoxicity in seedlings from both study conditions and dominated the plant material accumulated under the canopy for almost all of the phenological cycle. Soil analysis by GC-MS revealed the abundance of fatty acids and the presence of steroids. These results suggest that $A$. dealbata can control the growth of new conspecific seedlings under its own canopy, and improves the interspecific competitive performance of its adult plants in its non-native range.
\end{abstract}

KeYwords: Allelopathy, allelochemicals, biological invasions, intraspecific competition, morphological changes, nonnative range.

\section{RESUMEN}

La autotoxicidad es una forma particular de alelopatía y se sospecha que es responsable de regular la competencia intraespecífica bajo el dosel de Acacia dealbata Link (Fabaceae). Se estableció un bioensayo en condiciones controladas, siguiendo patrones naturales de la acumulación de material vegetal bajo el dosel de $A$. dealbata, para determinar los efectos de compuestos químicos liberados por hojas, corteza, flores y vainas de esta especie invasora en la germinación y el crecimiento inicial de plántulas conespecíficas. Mediante microscopia electrónica de barrido se evaluaron cambios morfológicos inducidos por las diferentes partes de $A$. dealbata en raíces de plántulas conespecíficas cultivadas en condiciones controladas y naturales. Se estudió la composición y el comportamiento de la fitotoxicidad del material vegetal depositado bajo el dosel de $A$. dealbata durante su ciclo fenológico. Se identificaron los principales compuestos químicos presentes en el suelo situado bajo el dosel. La mayoría de los órganos evaluados inhibieron la germinación y el crecimiento temprano de las plántulas, impidieron la formación de pelos radicales, destruyeron la rizodermis y alteraron el tejido parenquimático de las radículas. Las vainas provocaron la mayor autotoxicidad en ambas condiciones de estudio, y dominaron el material vegetal acumulado bajo el dosel por casi todo el ciclo fenológico. El análisis de suelos mediante GC-MS, reveló abundancia de ácidos grasos y presencia de esteroides. Estos resultados sugieren que A. dealbata puede controlar el crecimiento de nuevas plántulas conespecíficas bajo su propio dosel, y mejorar la competitividad interespecífica de sus plantas adultas en su rango no nativo.

Palabras clave: Alelopatía, aleloquímicos, invasiones biológicas, competencia intraespecífica, cambios morfológicos, rango no nativo. 


\section{INTRODUCTION}

Allelopathy includes harmful or beneficial effects of one plant on another plant by the production of chemical compounds that release into the environment (Rice 1984, Lambers et al. 2008, Ren et al. 2015). A particular form of allelopathy is autotoxicity, which occurs when the released chemical compounds inhibit the growth of plants of the same species (Miller 1996, Lambers et al. 2008, Yan et al. 2015). Consequently, autotoxicity can result in the inhibition of seedling growth or delayed germination, thus limiting the offspring (Falik et al. 2003). Such regulation could reduce the intensity of intraspecific competition and maximize the fitness of the dominant members of a population (Schenk et al. 1999). Usually, autotoxicity studies cover a wide range of taxonomically distant species and reveal different mechanisms of autotoxicity (Sinkkonen 2007). Residues of Daucus carota, Saccharum officinarum and Triticum aestivum, and root exudates of Cucumis sativus, Lolium perenne, Fragaria $x$ ananassa and Colocasia esculenta have been observed to cause autotoxic growth inhibition in several agricultural crops (Wu et al. 2001, Kraus et al. 2002, Ye et al. 2004, Jasicka-Misiak et al. 2005, Kitazawa et al. 2005, Sampietro 2006). In silviculture, autotoxins in litter and humus inhibit the reestablishment of several economically important conifers (Mallik 2002, Chen et al. 2005).

The autotoxic effects can reduce seed germination and seedling establishment of conspecific (Perry et al. 2005, Liu et al. 2008). Allelochemicals may be stored in glands and subsequently released into the environment (Nilsson et al. 1998, Kong et al. 2008, Ren et al. 2015). Further, some species are capable of detoxifying their own allelochemicals (Schulz \& Wieland 1999). Despite the multitude of adaptations, autotoxicity has been observed at all stages of plant growth. There have been decades of studies showing that autotoxicity can alter plant responses to population density in monospecific stands (Hirano \& Kira 1965, Jiang et al. 2013, Zhang et al. 2015, Bouhaouel et al. 2015, Yan et al. 2015).

Although allelopathy and autotoxicity are predominantly studied within an agricultural context (Miller 1996, Liu et al. 2008, Zhang et al. 2015), they can also play an important role in natural systems, for example, during succession (Wilson \& Rice 1968, Bonanomi et al. 2005) or exotic plant invasions (Callaway \& Aschehoug 2000, Hierro \& Callaway 2003). It has been suggested that the population density in stands of Acacia dealbata Link (Fabaceae) in a non-native range is regulated mainly by autotoxicity (Aguilera et al. 2015). This was corroborated by studies of shade tolerance involving this species, where it was observed absence of viable new seedlings under the canopy (Aguilera et al. 2015a). Recently, it has been reported that $A$. dealbata seedlings planted under their own canopy have difficulty growing (Fuentes-Ramírez et al. 2011). Taken together, these studies suggest that several traits make A. dealbata, an invasive species, successful in different Mediterranean ecosystems in the world (Richardson et al. 2011, FuentesRamírez et al. 2011, Rodríguez-Echeverría et al. 2013).

Some laboratory and field studies show evidence that $A$. dealbata has inhibitory effects on germination and early growth of other plant species; most of them being native understory shrubs and herbs (Carballeira \& Reigosa 1999, Lorenzo et al. 2008, Lorenzo et al. 2012). In addition, it is reported that $A$. dealbata induces changes in net photosynthesis and respiration rates of several native understory species in northwestern Spain (Lorenzo et al. 2011), as well as morphological changes (inhibition of root hairs formation, deformation and tissue destruction of rhizodermis, increase in thickness in the cell elongation zone, among others) on native seedlings from Mediterranean ecosystems of South America (Aguilera 2015, Aguilera et al. 2015b). The absence or scarcity of vegetation under the A. dealbata canopy is often attributed to an allelopathy phenomenon (Fuentes-Ramírez et al. 2011, Aguilera et al. 2015c), and, consequently, to the inhibitory effects from the secondary metabolites released by this species (Lorenzo et al. 2013, Aguilera et al. 2015). Aguilera et al. (2015d) identified biomolecules present in leaves, flowers, pods and the bark of $A$. dealbata that may be involved in this process, mainly to resorcinol, lupanine and stigmasterol.

It is hypothesized that new seedlings of $A$. dealbata do not survive under the canopy of conspecifics plants due to inhibition by autotoxicity. The aims of the present study are: (i) to determine the effect that different plant parts of invasive $A$. dealbata may have through direct contact of germination and early growth of conspecific plants, (ii) to assess whether morphological changes occur in radicles of A. dealbata seedlings by means of compounds released by conspecifics plants, (iii) to relate the phenological cycle of $A$. dealbata with the bioactive plant material naturally deposited under the conspecific canopy, and (iv) to identify chemicals with potential phytotoxic effects present in the soil under the $A$. dealbata canopy.

\section{MATERIALS AND METHODS}

STUdy AREA AND PLANT MATERIAL

The study area $(\sim 10 \mathrm{ha})$ is characterized by temperature of $12.4{ }^{\circ} \mathrm{C}$, relative humidity of $87.0 \%$ and annual average rainfall of $827.0 \mathrm{~mm}$ (Santibáñez \& Uribe 1993). The relief is undulating and the natural predominant vegetation is woodland, dominated by native trees belonging to Nothofagaceae family, besides Aristotelia chilensis (Molina) Stuntz and Drimys winteri J.R. Forst. et G. Forst. Also, there are many small stands of invasive $A$. dealbata and Teline monspessulana (L.) K. Koch occupying spaces free from 
native trees and edges of a path. Plant material (pods, leaves and flowers) of A. dealbata was collected in the campus of the University of Concepción ( $36^{\circ} 49^{\prime} 42.33^{\prime \prime} \mathrm{S}, 73^{\circ} 01^{\prime} 54.95^{\prime \prime}$ $\mathrm{W}$ at 62 m.a.s.l), under $A$. dealbata's canopy after natural deposition during 2014. The sampling was conducted in January for pods and seeds, and in June for leaves, bark and flowers (glomerulus globular inflorescence). Pods and seeds were collected and stored in closed plastic bags at $8{ }^{\circ} \mathrm{C}$ until they were used in the bioassays (June). The seedlings of $A$. dealbata $(\sim 7 \mathrm{~cm}$ from the root tip to the apical bud) from seeds naturally germinated under conspecific canopy were collected in May. These were carefully removed from the soil to prevent damage to the radicles, which can interfere with results of scanning electron microscopy.

\section{BIOASSAY}

This experiment was carried out under controlled conditions (temperature, light intensity, relative humidity and photoperiod) to avoid interference of multiple factors that can act simultaneously in natural conditions. Thus, it was possible to assess separately the autotoxicity potential of each plant material from A. dealbata. The plant parts that had naturally fallen under the A. dealbata canopy were quantified using 25 random quadrats of $63.6 \mathrm{~cm}^{2}$. Predominant plant material inside these quadrats was collected, weighed and used to calculate a biomass fall rate. Litter averages of the leaves, pods and flowers were 314.4, 518.8 and $518.8 \mathrm{~g} / \mathrm{m}^{2}$, respectively. The equivalent for Petri dish $\left(63.6 \mathrm{~cm}^{2}\right)$ was $2,3.3$ and $3.3 \mathrm{~g}$, respectively. Bark was extracted from five randomly selected trees and a pool was formed from them ( $3 \mathrm{~g}$ for Petri dishes). Each different type of plant material was placed into a Petri dish covered with a Whatman No 1 paper disc moistened with $20 \mathrm{ml}$ of distilled water. The standard amount of water was added as per previous successful experiments (Aguilera 2015). Petri dishes without of plant material and covered with Whatman No 1 paper disc moistened with $5 \mathrm{ml}$ of distilled water were used as a control. Thirty A. dealbata seeds were sown in each Petri dish, which were sealed with Parafilm ${ }^{\circledR}$ to prevent evaporation, and were incubated for 23 days in a growth chamber at a temperature of $20{ }^{\circ} \mathrm{C}$, relative humidity of $70-75 \%$ with a light/dark cycle of $12 / 12 \mathrm{~h}$ and inflorescent light of $80 \mu \mathrm{mol} \mathrm{m}^{-2} \mathrm{~s}^{-1}$. Seven replicates (Petri dishes) were maintained for each treatment (plant parts). The $\mathrm{pH}$ was measured directly in Petri dishes at the beginning and at the end of the experiment by $\mathrm{pH}$-indicator strips $\mathrm{pH} 0-14$ (Acilit ${ }^{\circledR}$ MERCK, Darmstadt, Germany), and ranged from 6 to 6.5 , an adequate value for the germination and seedling growth of $A$. dealbata (Dave's Garden 2010). Germination was calculated according to Fernandez et al. (2013) and the value was expressed as a percentage (GP). Radicle length (RL) and hypocotyl length (HL) of each seedling were measured. Additionally, necrosis of the radicle (RN) was assessed and classified according to five categories (Table 1).
SCANNING ELECTRON MICROSCOPY

Three-millimeter segments of root hair zone (ten from each treatment and ten segments from radicles of $A$. dealbata randomly collected under conspecific canopy in natural conditions) were fixed for $24 \mathrm{~h}$ in $2.5 \%$ glutaraldehyde in a sodium phosphate buffer $\mathrm{pH} 7.2$ at $4{ }^{\circ} \mathrm{C}$. They were then washed with a sodium phosphate buffer $(0.1 \mathrm{M})$ twice for $10 \mathrm{~min}$ each and fixed in osmium tetroxide $1 \%$ in a $0.1 \mathrm{M}$ sodium phosphate buffer for $2 \mathrm{~h}$ at $4{ }^{\circ} \mathrm{C}$. Thereafter, that they were washed with the same buffer twice for $10 \mathrm{~min}$ each time. The cross-section cuts consisted of thin sections (about $200 \mu \mathrm{m}$ ) and were cut with a rotation microtome HM 550 (MICROM International $\mathrm{GmbH}$, Walldorf). The samples were then dehydrated for a first time in a 30 $100 \%$ ethanol series and a second time in liquid $\mathrm{CO}_{2}$ by a critical point dryer (Balzers Union FL-9496, Holland) (Anderson 1951). Segments of root hair zone and cuts were immediately mounted on an aluminum sample holder with a carbon film, and were then gold plated by a metallizer (Edwards S 150 Sputter Coater, USA) for $3 \mathrm{~min}$ at $30 \mathrm{~mA}$, leaving a thickness of approximately $400 \AA$. Specimens were viewed under a scanning electron microscopy (SEM) (JEOL JSM- 6380 LV, Japan). A comparison of changes of root hair zone and tissues (rhizodermis, parenchyma cortex, endoderm and vascular tissue) was conducted between control and treatments.

MONITORING OF THE BIOACTIVE PLANT MATERIAL UNDER THE CANOPY

Ten stands of $A$. dealbata were selected for monitoring the relative proportion of the different plant parts naturally deposited, which accumulated under its canopy throughout the phenological cycle. Once a month from January to December 2014, a box of $0.50 \mathrm{~m}^{2}$ was launched randomly at five different points under the canopy of each stand. A pool was made of all plant material collected in the first 5 to 7 $\mathrm{cm}$ approximately. Then, the plant material was classified (pods, leaves, flowers, seeds) and weighed. Subsequently, the proportion of each plant material was determined and expressed in a percentage with respect to the total.

EXTRACTION AND IDENTIFICATION OF CHEMICAL COMPOUNDS FROM SOIL

Five different sampling points below the canopy of three $A$. dealbata stands were located at the study area. About 5 to 7 $\mathrm{cm}$ thickness of litter on the soil surface were removed and placed in paper bags to be carried to the laboratory. The soil samples were pooled to be homogenized in a single sample and spread on a surface in a thin layer to lessen the moisture for $72 \mathrm{~h}$ at room temperature. Subsequently, $2 \mathrm{~kg}$ of a pool of soil were weighed. Chemical extraction of soil was started with methanol for 10 days at $22{ }^{\circ} \mathrm{C}$. The resulting solutions were concentrated under reduced pressure with a rotatory evaporator (IKA HB10 digital, Staufen, Germany) 
to obtain the crude extracts. From the total extracts, $1 \mathrm{mg}$ was taken and diluted in $5 \mathrm{ml}$ of ethyl acetate. The sample was characterized by means of gas chromatography coupled to mass spectrometry (GC-MS) (Agilent 7890A, California, USA), with an Agilent 5975C mass detector, using a HP5MS type fused silica capillary column of $30 \mathrm{~m}, 0.25 \mathrm{~mm}$ inner diameter and $0.25 \mu \mathrm{m}$ film thickness, as follows:
Temperature: $250{ }^{\circ} \mathrm{C}$; Detector (mass): $280{ }^{\circ} \mathrm{C}$; Furnace: initial $100{ }^{\circ} \mathrm{C}$ for five min, increasing by $8{ }^{\circ} \mathrm{C} / \mathrm{min}$ up to $250{ }^{\circ} \mathrm{C}$ and maintained for $15 \mathrm{~min}$. The detector setting in scan mode ranged from 50 to $500 \mathrm{amu}$. The carrier gas flow (electronic degree helium) was at $1 \mathrm{ml} / \mathrm{min}$. The compound characterization was carried out by means of comparison with an NIST ${ }^{\circledR}$ database.

TABLE 1. Radical necrosis degree classification (Aguilera et al. 2015d). / Clasificación del grado de necrosis de la radícula (Aguilera et al. 2015d).

\begin{tabular}{cl}
\hline NECROSIS DEGREE & DESCRIPTION \\
\hline 0 & $\begin{array}{l}\text { Radicle without discoloration and with abundant root hairs } \\
\text { Radicle light brown and reduction of root hairs up to } 50 \% \text { of their length } \\
1\end{array}$ \\
2 & Radicle brown and 5 to $10 \%$ necrosis. No root hairs observed \\
3 & Radicle dark brown and $c a .50 \%$ necrosis. No root hairs observed \\
4 &
\end{tabular}

\section{StATISTICAL ANALYSES}

Experiments were established on a completely randomized experimental design. To test the effect of direct contact of plant parts from $A$. dealbata on its own GP, HL, RL and RN, a one-way ANOVA was applied and significant differences were further analyzed using Tukey's tests. Data normality and homogeneity of variances were respectively evaluated with Kolmogorov-Smirnoff and Levene tests. When the homogeneity of the variances was not achieved, data were Log $(\mathrm{n}+1)$ transformed (Zar 1996, Xie et al. 2000). KruskallWallis was applied when data or its transformations did not meet the assumptions for parametric statistics. The level of significance for all statistical analyses was fixed at $P<0.05$. All statistical analyses were performed using STATISTICA 8.0 for Windows (StatSoft Inc 2007).

\section{RESULTS}

EfFEcts of Plant Materials of $A$. DEALBATA ON CONSPECIFIC SEEDLINGS

The different parts of $A$. dealbata induced different responses on the germination of seeds and early growth of conspecific seedlings. In this context, the leaves and pods of this species inhibited significantly $(P<0.001)$ its own seed germination (Fig. 1). In particular, germination was approximately $5 \%$ due to direct contact with leaves and $20 \%$ by the pod treatments. Germination was not affected by contact with seeds, bark and flowers. However, the pods, leaves and flowers inhibited significantly $(P<0.001)$ the HL (Fig. 2a) and the RL (Fig. 2b) when compared to the control. The bark did not influence the RL, but it did influence the HL. The pods of $A$. dealbata caused necrosis (approximately grade 3 ) in radicles of conspecific seedlings (Fig 2c, Table 1), while the bark, flowers and leaves induced a similar degree of necrosis which were mostly brown and without root hairs.

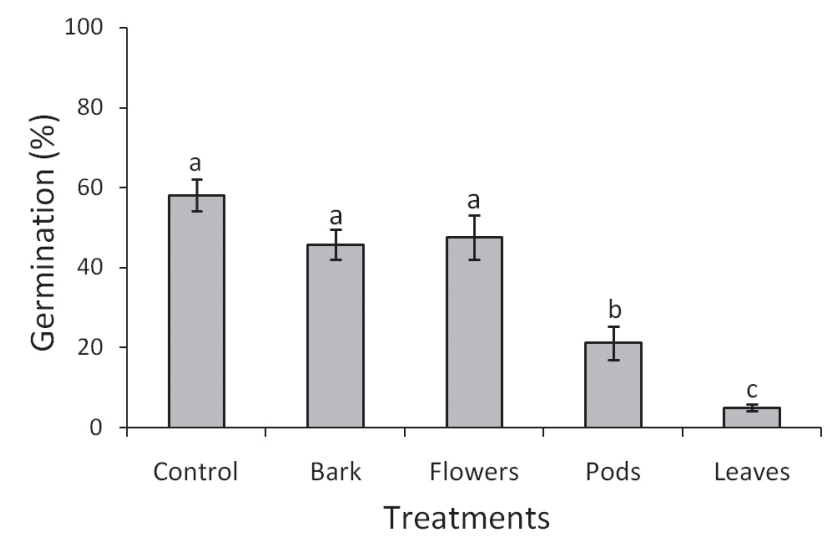

FIGURE 1. Effect of different Acacia dealbata parts on germination of conspecific seeds. Values shown are mean \pm SE. Different letters indicate significant differences between treatments after one-way ANOVA $(P<0.05)$ and Tukey's post hoc test. $/$ Efecto de diferentes partes de Acacia dealbata en la germinación de semillas conespecíficas. Valores mostrados son medias \pm ES. Distintas letras indican diferencia significativa entre tratamientos después de aplicar ANOVA de una vía $(P<0.05)$ y la prueba post hoc de Tukey. 
MoRPhOlOGiCAL EFFECTS AT A RADICLE LEVEL

The micrographs from the SEM showed that $A$. dealbata in early stages of growth have few root hairs. This was confirmed in the control treatment of the root hairs zone (Fig. 3a). Nevertheless, small root hairs can be observed throughout that area, as well as the superficial cell layers of the rhizodermis. However, this did not occur due to the action of the different parts of $A$. dealbata in the conspecific radicle. In the presence of all plant parts, the formation of root hairs was inhibited and the rhizodermis was affected
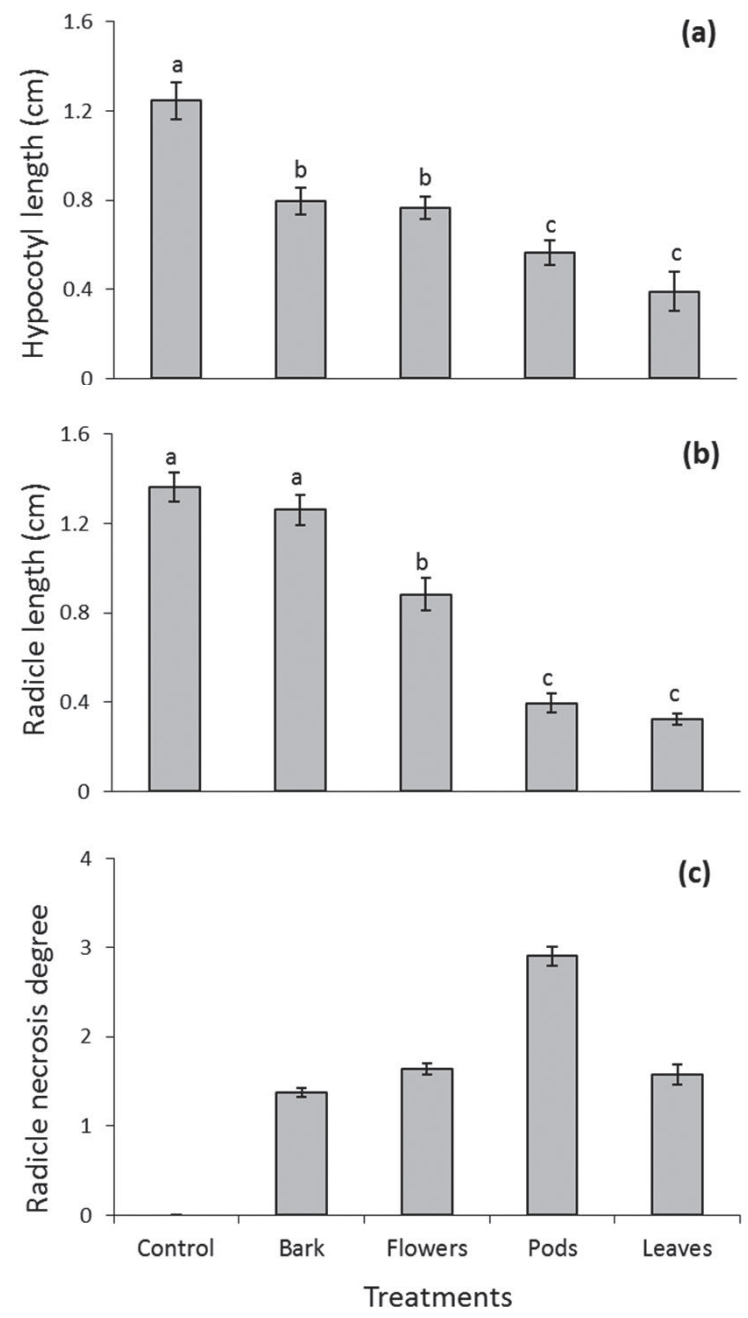

FiguRE 2. Effect of different Acacia dealbata parts on hypocotyl length (a), radicle length (b) and radicle necrosis degree (c) of conspecific seedling. Different letters indicate significant differences between treatments after one-way ANOVA $(P<0.05)$ and Tukey's post hoc test; in (c) nonparametric Kruskal-Wallis analysis was applied. / Efecto de diferentes partes de Acacia dealbata en la longitud del hipocótilo (a), longitud de la radícula (b) y grado de necrosis en la radícula (c) de plántulas conespecíficas. Distintas letras indican diferencia significativa entre tratamientos después de aplicar ANOVA de una vía $(P<0.05)$ y la prueba post hoc de Tukey; en (c) se aplicó el análisis no paramétrico de Kruskal-Wallis. with varying intensities. For example, it appears that the flowers (Fig. 3b) caused more damage to the inner layers of the rhizodermis than the bark (Fig. 3c). At the same time, the rhizodermis was destroyed by the action of the leaves (Fig. 3d). Similarly, the pods (Fig. 3e) destroyed the cell layers of the rhizodermis, but the appearance of the damage was different than the other plant parts. However, it is worth noting that the damage observed in the root hair zone of radicles from natural conditions (Fig. 3f) was relatively similar to the damage caused by pods in the controlled conditions.

For cross-sections corresponding to the root hair zone, the control (Fig. 4a) showed the presence of a few root hairs and the normal conformation of internal tissues. The flowers (Fig. 4b) inhibited the formation of root hairs, but did not affect the internal tissues of the $A$. dealbata radicle. However, the bark (Fig. 4c) and leaves (Fig. 4d) induced small changes in the isodiametric and polyhedral conformation of cells. Furthermore, the pods (Fig. 4e) caused internal compaction at tissue level interfering the cortex tissue differentiation and vascular connection. At the same time, the cross-section made in seedling radicles from natural conditions (Fig. 4f) showed changes in the isodiametric and polyhedral cell structure of parenchymatous tissue. In this case, damages in the vascular tissues were not observed.

COMPOSITION OF BIOACTIVE PLANT MATERIAL UNDER THE CANOPY THROUGHOUT THE PHENOLOGICAL CYCLE

The natural deposit of plant material under the $A$. dealbata canopy occurred throughout its phenological cycle. This deposit was distinguished both quantitatively and qualitatively in each phenological stage. From May to June, the pods from the previous harvest, dominated almost $100 \%$ of plant material under the canopy (Fig. 5, Fig. 6c). The floral primordia of $A$. dealbata became visible in early March. The flowers (glomerulus globular inflorescence) were fully formed in early June, while many of them began to be deposited under the canopy from that moment to September or early October (Fig. 5, Fig. 6a). Flowers predominated under the canopy at least $70 \%$ between June and August and pods did not exceed $25 \%$ of the plant material mixture in the same period (Fig. 5). The flowers and pods formed a layer of 1 to $3 \mathrm{~cm}$ above the soil surface and under the $A$. dealbata canopy (Fig. 6a, 6c). This layer covered the entire surface of the soil under the canopy, except when the stand was located on steep slopes. In such cases, there were empty spaces at the top of the slope, apparently caused by rain runoff. From September on, the flower proportion decreased progressively in the plant material and again pods began to dominate with $60 \%$ of the mixture (Fig. 5). The flowers' decomposition under the canopy was quick. For example, the flowers that were deposited during July and August were decomposed in September. From this moment until October, pods, old leaves and fresh leaves were present in the plant 
material mixture (Fig. 5, Fig. 6b). However, pods remained throughout the phenological cycle and their decomposition was slow (Fig. 6d). Moreover, the leaves always formed the minor portion of plant material mixture under the canopy throughout the phenological cycle, oscillating between 2 and $8 \%$ (Fig. 5).
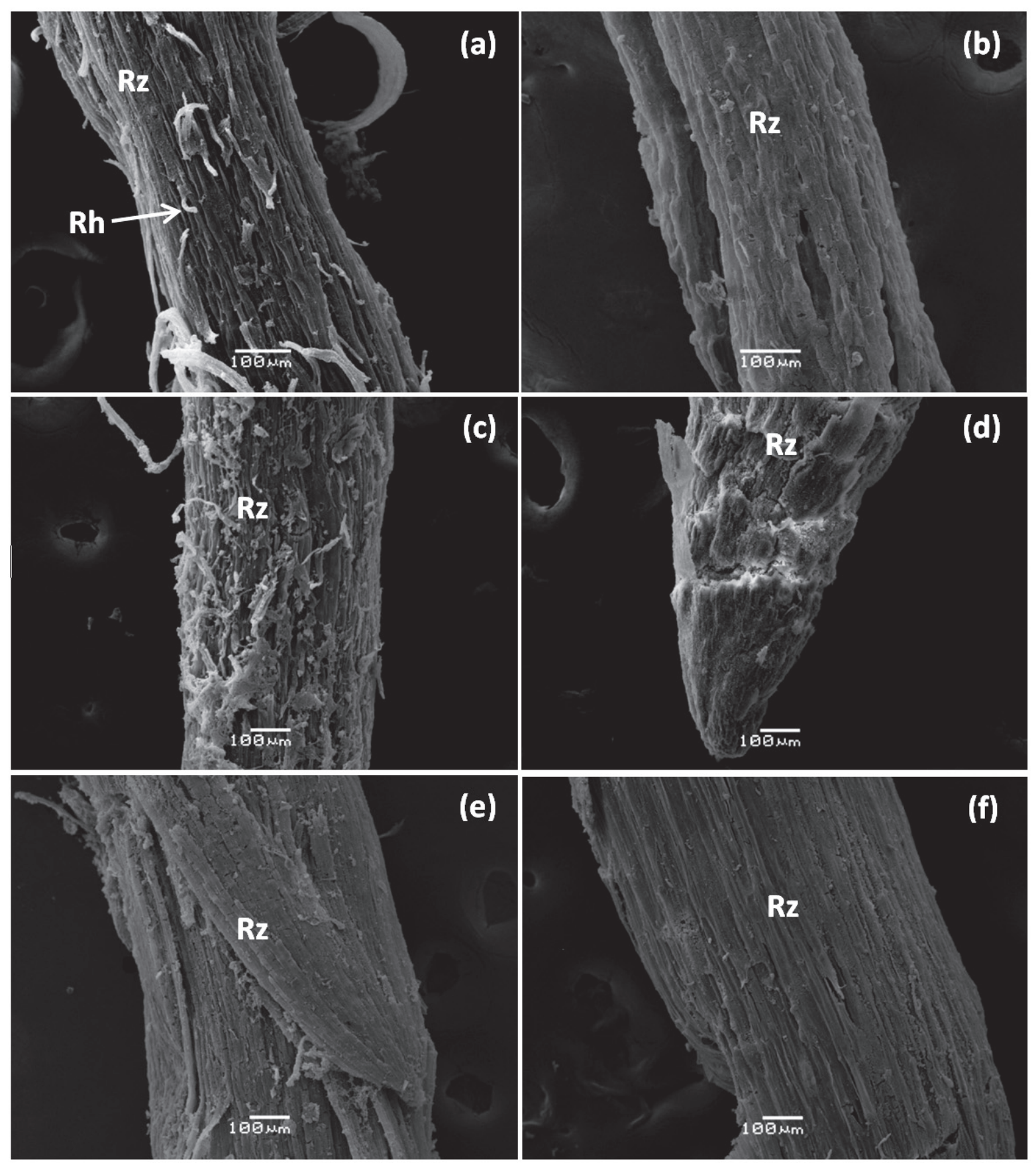

FiguRE 3. Effect of different Acacia dealbata parts on root hair zone of conspecific seedlings. Presence of Rh and normal Rz in control (a); inhibition of Rh formation and destruction of Rz by flowers (b), bark (c), leaves (d), pods (e), and in radicles of seedlings developed in natural conditions (taken from under the A. dealbata canopy) (f). Rh: root hairs, Rz: rhizodermis. / Efecto de diferentes partes de Acacia dealbata en la zona de pelos radicales de plántulas conespecíficas. Presencia normal de Rh y Rz en el control (a); inhibición de la formación de Rh y destrucción de Rz por bioactividad de flores (b), corteza (c), hojas (d), vainas (e), y en radículas de plántulas desarrolladas en condiciones naturales (tomadas debajo del dosel de $A$. dealbata) (f). Rh: pelos radicales, Rz: rizodermis. 
Autotoxicity of the invasive Acacia dealbata: Aguilera, N. ET AL.
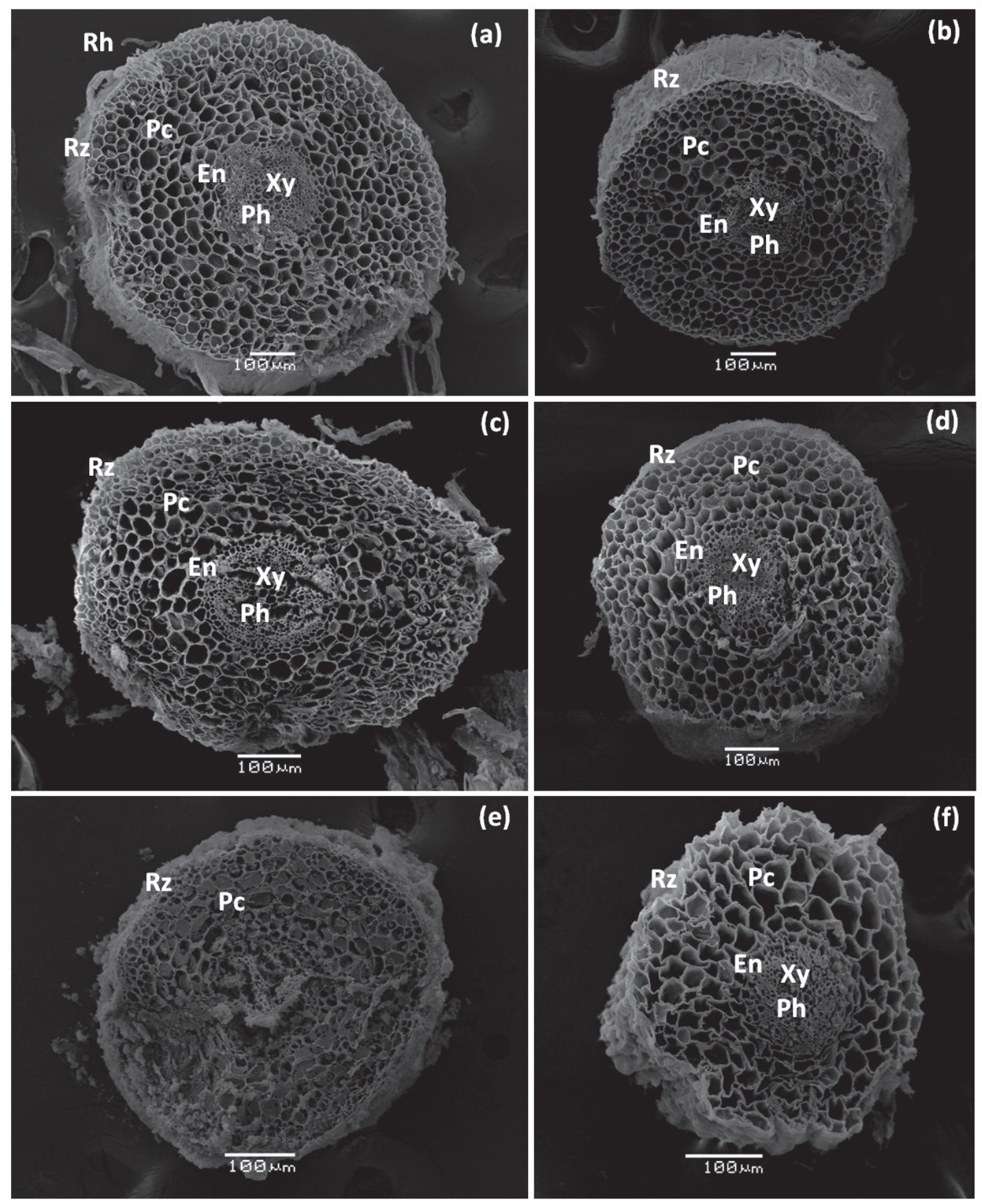

Figure 4. Effect of different Acacia dealbata parts on a root hair zone (cross-section) from radicles of conspecific seedlings. Normal cell and tissue structures in the control (a), no changes in cells and tissues induced by flowers (b), few changes in the polyhedral and isodiametric structure of parenchyma cells induced by bark (c) and leaves (d), compaction at cortex level and the tissue differentiation and vascular connection were lost by pods effect (e), changes in the polyhedral and isodiametric structure of parenchyma cells in radicles of seedlings developed in natural conditions (taken from under the A. dealbata canopy) (f). Pc: parenchyma cortex, En: endoderm, Ph: phloem, Xy: xylem. Rh: root hairs, Rz: rhizodermis. / Efecto de diferentes partes de Acacia dealbata en la zona de pelos radicales (corte transversal) de raíces de plántulas conespecíficas. Estructuras celulares y tisulares normales en el control (a), ausencia de cambios en células y tejidos por bioactividad de flores (b), pocos cambios en las estructuras poliédricas e isodiamétricas de las células del parénquima por bioactividad de corteza (c) y hojas (d), compactación a nivel de córtex y pérdida de diferenciación tisular y conexión vascular por efecto de vainas (e), cambios en las estructuras poliédricas e isodiamétricas de las células del parénquima de radículas de plántulas desarrolladas en condiciones naturales (tomadas debajo del dosel de $A$. dealbata) (f). Pc: parénquima cortical, En: endodermis, Ph: floema, Xy: xilema. $\mathrm{Rh}$ : pelos radicales, Rz: rizodermis. 


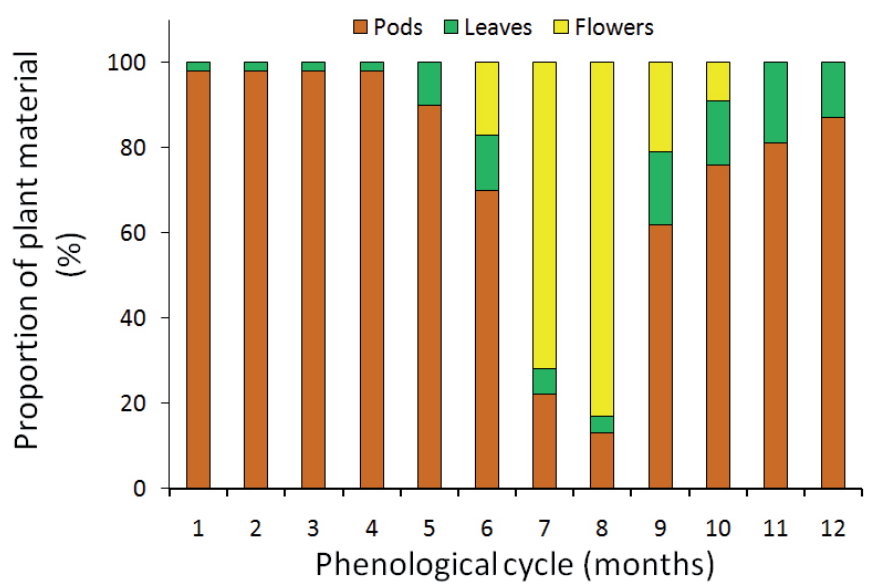

Figure 5. Relative proportion of plant material of Acacia dealbata deposited under its canopy throughout its phenological cycle. On the X axis, 1 corresponds to January and the months continue consecutively until December (12). / Proporción relativa del material vegetal de $A$. dealbata depositado bajo su dosel a través del ciclo fenológico. En el eje X, 1 corresponde a enero y los meses continúan consecutivamente hasta diciembre (12).
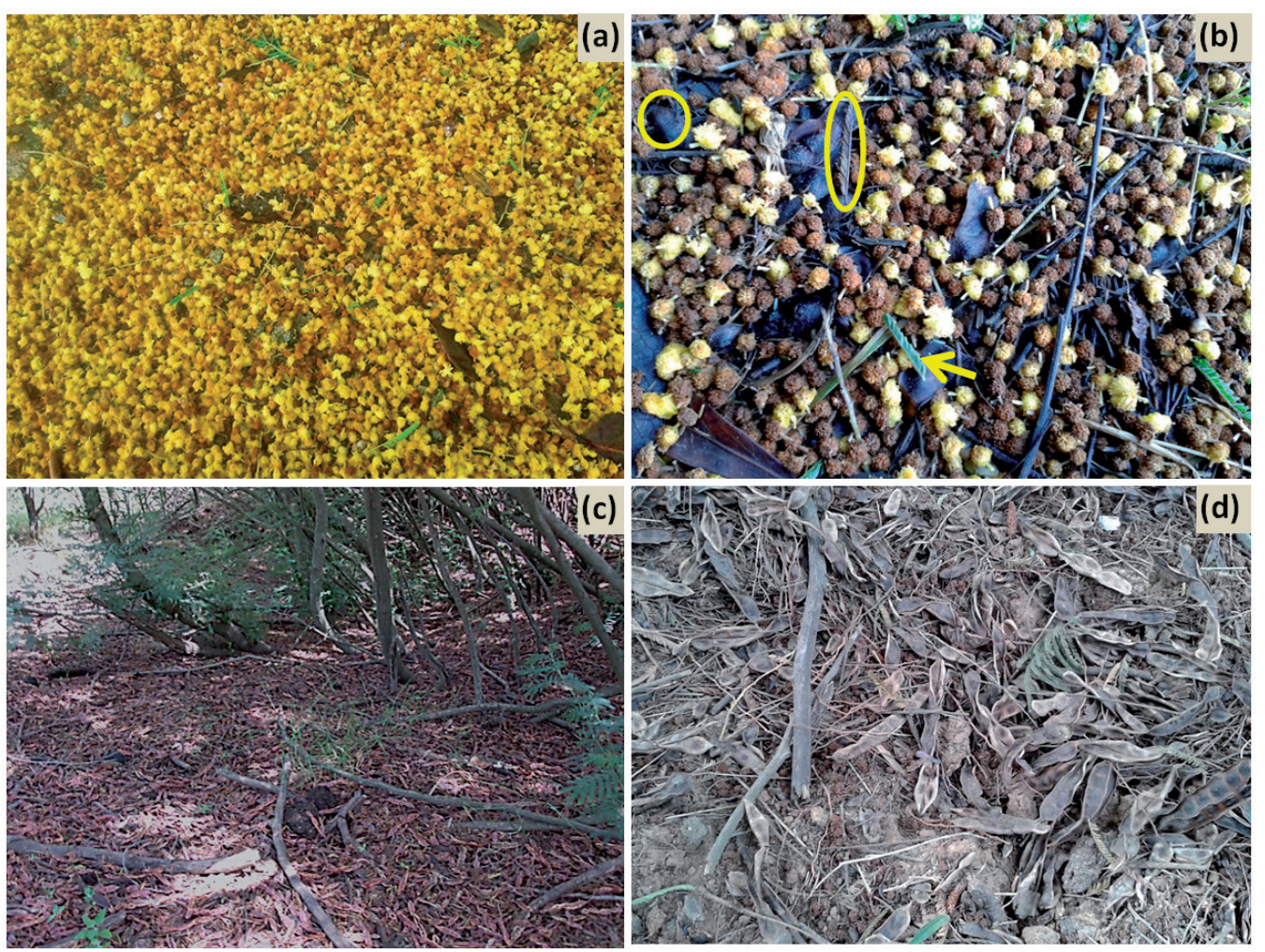

Figure 6. Predominant plant material of Acacia dealbata under its canopy at different times of its phenological cycle. Ground covered by fresh flowers during the flowering period (June to August) (a), flowers in decaying process, pods from the previous harvest, fresh leaves and old leaves were observed in September (b), ground were covered by pods from January to May (c), pods have a slow of decomposition process and remain until December ( $\sim 11$ months of being deposited naturally) to be enriched subsequently with a new litter of the next of harvest pods (January to February) (d). In (b) presence of pods is indicated by a circumference, the old leaves by an ellipse and the fresh leaves by an arrow. / Material vegetal de Acacia dealbata predominante bajo su dosel en diferentes momentos del ciclo fenológico. Suelo cubierto por flores frescas durante el período de floración (junio a agosto) (a), en septiembre se observaron flores en proceso de descomposición, vainas de la cosecha anterior, hojas frescas y hojas viejas (b), suelo cubierto por vainas de enero a mayo (c), vainas tienen lento proceso de descomposición y permanecen hasta diciembre $(\sim 11$ meses de haber sido depositado de forma natural $)$ para ser enriquecidas posteriormente con una nueva camada de la próxima cosecha de vainas (enero-febrero) (d). En (b) la presencia de vainas se indica por una circunferencia, las hojas viejas por elipse y hojas frescas por una flecha. 
Potential PHYTOTOXIC COMPOUNDS IN SOIL

The most abundant compounds detected in the soil sample were fatty acids. Some of them were abundant; for example: hexadecanoic acid, methyl ester (retention time, RT: 13.600), 9,12-octadecadienoic acid, methyl ester, (E,E)(RT: 15.233), and octadecanoic acid, methyl ester (RT: 15.496) (Fig. 7). However, from the standpoint of phytotoxic interest, three aromatic compounds were identified although in much less abundance than the fatty acids mentioned above (Fig. 7, Fig. 8). The mass spectrum shows a RT: 22.195 for anthiaergosatn-5,7,9,22-tetraen, 3-acetoxy- (compound 1); RT: 23.831 for tetracyclo $[11.4 .0 .0(3,11) .0(7,11)]$ heptadeca1(13),14,16-triene-4-carboxylic acid, 14,17-dimethoxy-8(2-hydroxy-1-methylethyl)- (compound 2); and RT: 26.304 for desmosterol (compound 3) (Fig. 7).

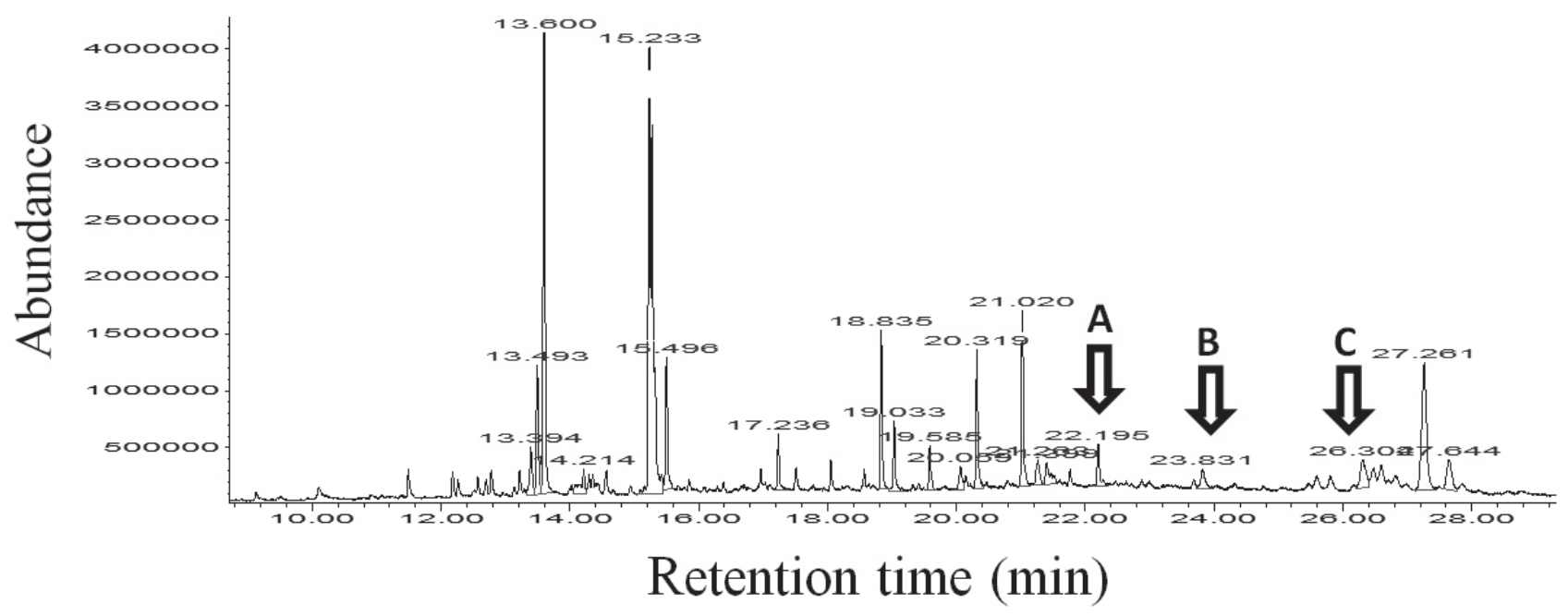

FIGURE 7. Mass spectrum obtained from the methanolic extract of soil collected under the Acacia dealbata canopy. The letters above the arrows indicate that peaks belong to compound 1 (A), compound 2 (B) and compound 3 (C). These compounds are shown in Figure 8 . / Espectro de masas obtenido a partir del extracto metanólico de suelo recogido bajo el dosel de Acacia dealbata. Las letras encima de las flechas indican que los picos pertenecen al compuesto 1 (A), compuesto 2 (B) y compuesto 3 (C). Estos compuestos se muestran en la Figura 8.

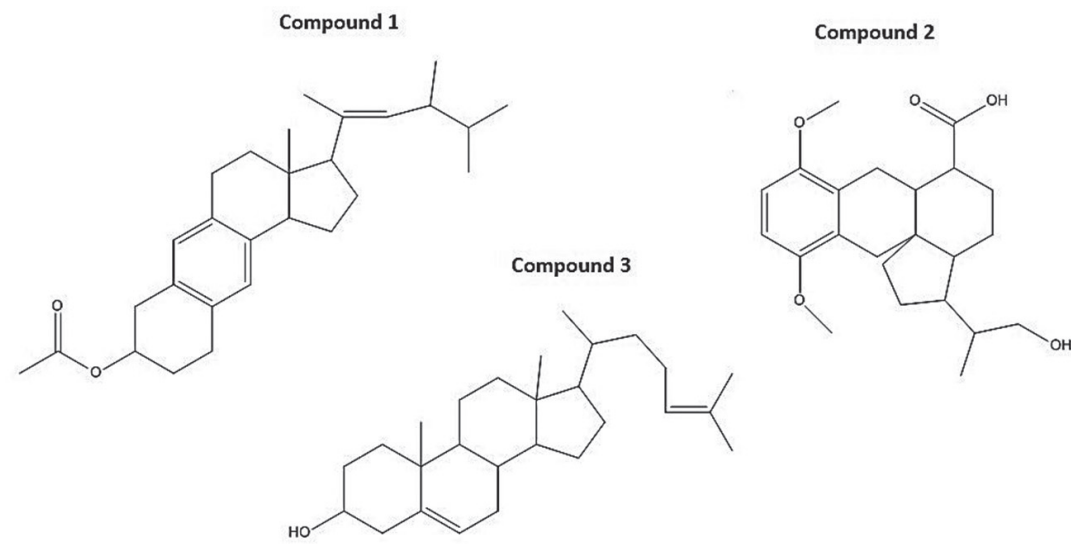

FiguRE 8. Structures of three putative phytotoxic compounds identified from methanolic extracts of soil collected under the Acacia dealbata canopy. Compound 1: Anthiaergosatn-5,7,9,22-tetraen, 3-acetoxy-, Compound 2: Tetracyclo[11.4.0.0(3,11).0(7,11)]heptadeca1(13),14,16-triene-4-carboxylic acid, 14,17-dimethoxy-8-(2-hydroxy-1-methylethyl)- and Compound 3: Desmosterol. / Estructuras de tres supuestos compuestos fitotóxicos identificados a partir de extractos metanólicos de suelo recogido bajo el dosel de Acacia dealbata. Compuesto 1: Antiaergosatn- 5,7,9,22-tetraeno, 3- acetoxi-, Compuesto 2: Tetracíclo[11.4.0.0(3,11).0(7,11)] heptadeca-1(13),14,16-trieno4-ácido carboxílico, 14,17- dimetoxi-8-(2-hidroxi-1- metiletil)- y Compuesto 3: Desmosterol. 


\section{DISCUSSION}

The present study showed that all plant parts can cause inhibition on the germination and early growth of seeds of $A$. dealbata deposited under the canopy of this same species. Thus, despite the thousands of seeds that are produced by $A$. dealbata on each harvest, apparently, the plant limits itself or prevents intraspecific competition for resources (Schenk et al. 1999, Falik et al. 2003). Only a small proportion of seeds are able to germinate in such conditions. Therefore, the new seedlings are constantly subjected to the impact of allelochemicals released from the different parts of their mother plant. Altogether, the model bioassay based on direct contact between the plant material with the target seeds can approach to what occurs in natural conditions. In this sense, short-term bioassays in controlled environments are a first attempt to assess the occurrence of allelopathy (An et al. 1993, Canals et al. 2005). The idea that the impact of allelochemicals released by the different plant parts can be a chronic process was considered (Pedrol et al. 2006, Graña et al. 2013). It is most likely that this phenomenon occurs in several ways, because each of the plant parts releases different phytotoxic compounds that might have different modes of action (Hol et al. 2003). At the same time, the phytotoxic activity of plant materials could be combined and strengthened throughout the phenological cycle (Aguilera 2015, Aguilera et al. 2015d). In this context, A. dealbata tends to exert a constant phytotoxic pressure over its own seedlings produced from seeds and prevents these from becoming established under its parent canopy. This means that this invader plant may have been able to use its allelochemical potential to regulate the population of new seedlings of the same species.

The autotoxic effect caused by different plant parts was accentuated by morphological changes or damage at the radicle level. On the one hand, the plant parts inhibited root hair formation and contributed to the destruction of the rhizodermis and the internal root tissues (Graña et al. 2013, Aguilera et al. 2015b). It is important to consider the strong phytotoxic activity induced by pods of $A$. dealbata on radicles of new seedlings. In this case, the internal tissues of radicles collapsed completely and vascular connection was lost. All of these morphological changes showed that some allelochemicals alter cell membranes by disrupting the permeability, ion flow and hydraulic activity at the root level, resulting in cascading effects that can cause severe damage to the stomatal function and the photosynthesis and respiration rates (Einhellig 2004). Similar morphological results were obtained by direct contact of $A$. dealbata parts with radicles of model species (Lactuca sativa L.) and the native species (Quillaja saponaria Molina) that shares the same distribution range of $A$. dealbata in Chile (Aguilera et al. 2015b, 2015c). These authors found that leaves of $A$. dealbata caused damage at the radicle level, similar to the morphological alterations induced by the pods in the present work. It is very interesting that the morphological alterations shown by the seedling roots of $A$. dealbata found in natural conditions were similar to the morphological alterations in the radicles of their own species shown due to direct contact by pods under controlled conditions. In particular, the same damage occurred at the rhizodermis level.

In general, the most intense autotoxic effects that compromised the survival of $A$. dealbata seedlings were induced at the radicle level. Radicle elongation and other morphological changes at the root level have been reported to be more sensitive to allelochemicals when compared to seed germination and hypocotyl elongation (Carballeira \& Reigosa 1999, Chon et al. 2002, Fritz et al. 2007, Coelho de Oliveira et al. 2008, Hussain et al. 2011). In this context, it is clear that all parts of $A$. dealbata that were tested expressed autotoxic biological activity. However, the pods and leaves were the most effective. The case of the pods is particularly interesting because they remained under the canopy throughout the phenological cycle of $A$. dealbata. At the same time, the pods dominated the plant material deposited under the canopy, except in July and August when the flowers prevailed. This means that the pods can constantly release phytotoxic compounds. Nevertheless, other studies have shown that pods have a strong bioactivity for four months after deposition under the canopy, but the bioactivity progressively decreases after seven months (Aguilera et al. 2015d). The pods from the next harvest may be deposited on the litter pods for advanced decomposition of the previous harvest. Thus, a harvest of pods can overlap with the other one, and the litter can continuously maintain phytotoxicity.

Because $A$. dealbata is an evergreen species (Lorenzo et al. 2010a), the leaves found under canopy are a low relative proportion of the plant material deposited during the phenological cycle of this invasive species, especially in very windy periods. The highest percentages of leaves found registered under the canopy between June and September were due to strong winds typical of this season in south central Chile (Santibáñez \& Uribe 1993). The possible impact of phytotoxicity from flowers was for a short time, because they only dominated the plant material mixture under the canopy from June to September. During September, after just four to five weeks the flowers degraded completely, and once again the litter began to be dominated by pods. Moreover, aqueous extracts from $A$. dealbata bark also induced morphological changes and inhibition on its own seedlings, though less intense than what is caused by other plant parts. This revealed that the bark can release allelochemicals (Karmegam et al. 2014) when branches and stems are washed by rain or heavy fog. Therefore, these compounds can be routinely incorporated into the substrate located under the canopy and can increase the impact of a chronic phytotoxic effect on its own seeds or seedlings, as 
well as on other plants species of competitive importance for this invasive species (Souza et al. 2010).

Several studies reveal that chemical compounds naturally released by $A$. dealbata have shown allelopathic effects on seed germination, seedling growth, net photosynthetic and respiration rates of agricultural and understory plants, as well as on functional diversity and structure of soil microbes in the invaded range (Carballeira \& Reigosa 1999, Lorenzo et al. 2008, Lorenzo et al. 2013). In this regard, a recent study conducted in the Northwest of Spain showed that volatile organic compounds released from fresh flowers of A. dealbata inhibited germination and seedling growth of Trifolium subterraneum L., Lolium multiflorum Lam. and Medicago sativa $\mathrm{L}$. native to the region (Souza-Alonso et al. 2014). Moreover, in South America, some different nonvolatile compounds present in leaves, flowers, pods and bark of $A$. dealbata have been identified. Of all of them, the most predominant were resorcinol and moretenone in leaves, stigmasterol, D-alpha-tocopherol quinone and lupanin in pods, and methyl p-anisate, p-anisyl alcohol, stigmasterol and anisal in flowers (Aguilera 2015, Aguilera et al. 2015d). These authors also believe that these compounds are responsible of inhibition of germination and growth of Lactuca sativa as a model species, and of various native herbaceous plants (e.g. Helenium aromaticum (Hook.) H.L. Bailey and Rodophiala maculate (L'Hér.) Ravenna and trees species (e.g. Quillaja saponaria).

Presently, there is no evidence that phytotoxic compounds released by $A$. dealbata were identified directly in the soil. Concerning this, there is an extensive discussion regarding the influence of microorganisms on the allelochemicals released by donor species into soil (Inderjit \& Weiner 2001, Inderjit \& Nilsen 2003, Inderjit 2005, Inderjit et al. 2011, Zen 2014). It is suspected that some compounds identified in different plant parts of $A$. dealbata may be altered in soil, changing the phytotoxic effects. In the present study, abundant fatty acids were identified in the soil under the A. dealbata canopy. Such compounds might be a natural source of energy of soil microorganisms, but have also been mentioned as allelochemicals (Olofsdotter 1998, Blanco et al. 2006). Although less abundant, three aromatic compounds were also identified that may be from plant origin. Of these, compound 1 and compound 3 can be classified as steroids according to their chemical structure. Coincidentally, an abundant presence of stigmasterol was detected in the flowers and pods (Aguilera et al. 2015d). This steroid has been related to bioactivity in cycle and cellular division (Sandjo et al. 2011). The chemical structure of stigmasterol and the compounds identified in the soil are very similar. This suggests that $A$. dealbata is an important source of steroids (among other compounds) that are released to the ground, which would expose them to possible changes caused by the microorganisms present in the soil. Additionally, the long stay of the pods under the canopy could be a systematic source of steroid leachate in the ground. Finally, it is important to consider that the seeds of A. dealbata or other cohabiting species mainly make direct contact with the plant material litter found on the ground under the canopy. In this way, the target seeds could receive the direct impact of several phytotoxic compounds that are released by different plant materials from $A$. dealbata that make up the litter throughout the entire phenological cycle of this invader species.

Many plants have well-known attributes (e.g. abundant and wind-dispersed seeds, breakdown of seed dormancy mechanisms, and rapid and early growth) that allow a rapid build-up of populations under appropriate conditions (Bazzaz \& Morse 1991). However, their ability to regulate their own decline is not fully understood (Canals et al. 2005). In fact, Lorenzo et al. (2010b) has shown stimulation of $A$. dealbata seeds watered with natural extracts (rain extracts) or litter extracts. Canals et al. (2005) reported that autotoxicity may play a prime role as a population regulator. Inhibitory chemically mediated interactions may maintain the spacing of individuals and prevent density dependent mortality processes, thus ensuring self-perpetuation (Murray 1998). For example, autotoxins from decaying shoots of Centaurea maculosa L. and Juncus effusus L. have been shown to inhibit the germination and the early growth of seedlings of the same species (Ervin \& Wetzel 2000, Perry et al. 2005). In mathematical modeling studies (considering several ecologically possible relationships between plant density and autotoxin exposure) autotoxicity has been concluded to affect the outcome of density dependent dose-response experiments (Sinkkonen 2007). These studies support the need to take into account the autotoxic potential of $A$. dealbata to explain self-regulation of the establishment of new seedlings under its canopy (Singh $e t$ al. 2010). Chemicals can enter the soil under the canopy through foliar leaching, root exudation, decomposition of plant tissues, or volatilization (Inderjit \& Nilsen 2003, Lipinska \& Harkot 2007). Thus, in this particular case, the donor and recipient of allelochemicals was the same plant. This process could strengthen the competitiveness of $A$. dealbata by minimizing intraspecific competition.

In summary, this study is the first approach known (combining morphometric, morphological, phenological and chemical studies) to explain the early death and absence of new A. dealbata plants from the gamic reproduction plants under its own canopy. The bioassay under controlled conditions allowed us to determine that most of the tested plant parts inhibited germination and the early seedling growth. All plant parts caused morphological alterations at the radicle level that compromise the plant survival in the short term. Particularly, the pods caused the most autotoxicity and dominated the plant material that had been accumulated under the $A$. dealbata canopy for almost all of the phenological cycle. The bioactivity of the pods in natural 
conditions was confirmed by the morphological changes shown in radicles of the $A$. dealbata seedlings developed in natural conditions (taken from under the $A$. dealbata canopy). These facts are consistent with the identification of several compounds in the soil under the canopy, especially steroids, which are very similar in the chemical structure to the stigmasterol detected in flowers and pods of this invasive species. Such compounds, like others, were highly bioactive in previous studies (Aguilera 2015, Aguilera et al. 2015d). Therefore, the fact that $A$. dealbata can release autotoxic compounds throughout its phenological cycle can help regulate intraspecific competition under its canopy. This phenomenon has ecological relevance to the invasive process of $A$. dealbata in its non-native range, because it improves the adult plant's performance and competitive capability. Focused studies will be needed to find links between the compounds present in the plant and the dynamics of the same after being released into the soil to better clarify this complex relationship of plant-soil-plant from the perspective of chemical ecology.

\section{ACKNOWLEDGMENTS}

This research was supported by the Vice-Rectory of Research and Development of the University of Concepción and the Project VRID-215.142.034-1.0IN. The authors are grateful for Mr. Alexis O. Estay for his contribution to the SEM technique and for Mrs. Isabel Moraga and Mr. Ian Scott for the revision of the manuscript's English.

\section{REFERENCES}

Aguilera, N. 2015. Allelopathic effects of Acacia dealbata Link (Fabaceae:Mimosoideae) in Mediterranean ecosystems in south central Chile. PhD dissertation. Facultad de Ciencias Naturales y Oceanográficas, Universidad de Concepción, Concepción, Chile. 99 pp.

Aguilera, N., Sanhueza, C., Guedes, L.M., Becerra, J., Carrasco, S., Hernández, V. 2015a. Does Acacia dealbata express shade tolerance in Mediterranean forest ecosystems of South America? Ecology and Evolution 5: 3338-3351.

Aguilera, N., Guedes, L.M., Becerra, J., Baeza, C., Hernández, V. 2015b. Morphological effects at radicle level by direct contact of invasive Acacia dealbata Link. Flora 215: 5459.

Aguilera, N., Guedes, L.M., Becerra, J., Villaseñor-Parada, C., González, L., Hernández, V. 2015c. Allelopathic effect of the invasive Acacia dealbata Link (Fabaceae) on two native plant species in south-central Chile. Gayana Botánica 72: 231-239.

Aguilera, N., Becerra, J., Lorenzo, P., Villaseñor-Parada, C., González, L., Hernández, V. 2015d. Effects and identification of chemical compounds released from the invasive Acacia dealbata Link. Chemistry and Ecology
31: 479-493.

Anderson, T.F. 1951. Techniques for preservation of three dimensional structure in preparing specimens for the electron microscope transactions. New York Academy of Sciences. Series 11, 13: 130-134.

An, M., Johnson, I.R., LovetT, J.V. 1993. Mathematical modelling of allelopathy: biological response to allelochemicals and its interpretation. Journal of Chemical Ecology 19: 23792388.

Bazzaz, F.A., Morse, S.R. 1991. Annual plants: potential responses to multiple stresses. In: H.A Mooney, W.E. Winner \& E.J. Pell (eds.), Response of Plants to Multiple Stresses, pp. 283-301. Academic Press Inc, New York.

Blanco, Y., Hernández, I., Urra, I., Leyva, Á. 2006. El uso de la alelopatía y sus efectos en diferentes cultivos. Revista Cultivos Tropicales 23: 5-16.

Bonanomi, G., LegG, C., Mazzoloni, S. 2005. Autoinhibition of germination and seedling establishment by leachate of Calluna vulgaris leaves and litter. Community Ecology 6: 203-208.

Bouhaouel, I., Gfeller, A., Fauconier, M.L., Rezgui, S., Amara, H.S., Du JARDIN, P. 2015. Allelopathic and autotoxicity effects of barley (Hordeum vulgare L. ssp. vulgare) root exudates. Biocontrol 60: 425-436.

Callaway, R.M., Aschehoug, E.T. 2000. Invasive plants versus their new and old neighbors: A mechanism for exotic invasion. Science 290: 521-523.

Canals, R.M., Emeterio, L.S., Peralta, J. 2005. Autotoxicity in Lolium rigidum: analyzing the role of chemically mediated interactions in annual plant populations. Journal of Theoretical Biology 235: 402-407.

Carballeira, A., Reigosa, M.J. 1999. Effects of natural leachates of Acacia dealbata link in Galicia (NW Spain). Botanical Bulletin of Academia Sinica 40: 87-92.

Chen, L.C., Wang, S.L., Yu, X.J. 2005. Effects of phenolics on seedling growth and N-15 nitrate absorption of Cunninghamia lanceolata. Allelopathy Journal 15: 57-65.

Chon, S., Chol, S., Jung, S., JAng, H., Pyo, B., Kim, S. 2002. Effects of alfalfa leaf extracts and phenolic allelochemicals on early seedling growth and root morphology of alfalfa and barnyard grass. Crop Protection 21: 1077-1082.

Coelho de Oliveira, D., Gonçalves, G.L., Dos Santos, R.M. 2008. Phytotoxicity of the extracts of Lonchocarpus muehlbergianus Hassl. (Fabaceae) leaflets and galls on seed germination and early development of lettuce. Acta Botanica Brasilica 22: 1095-1100.

Dave's Garden. 2010. Mimosa, silver wattle Acacia dealbata. Available in: http://davesgarden.com/guides/pf/go/2499/\#b. Accessed 31 May 2015.

Einhellig, F.A. 2004. Mode of allelochemical action of phenolic compounds. In: F.A. Macias, J.C.G. Galindo, J.M.G. Molinillo \& H.G. Cutler (eds.), Allelopathy: Chemistry and mode of action of allelochemicals, pp. 217-238. CRC Press, Boca Raton.

Ervin, G.N., WetZel, R.G. 2000. Allelochemical autotoxicity in the emergent wetland macrophyte Juncus effusus (Juncaceae). American Journal of Botany 87: 853-860.

Falik, O., Reides, P., Gersani, M., Novoplansky, A. 2003. Self/ non-self discrimination in roots. Journal of Ecology 91: $525-531$ 
Fernandez, C., Santoja, M., Gros, R., Monnier, Y., Chomel, M., Baldy, V., Bousquet-Mélou, A. 2013. Allelochemicals of Pinus halepensis as drivers of biodiversity in mediterranean open mosaic habitats during the colonization stage of secondary succession. Journal of Chemical Ecology 39: 298-311.

Fritz, D., Bernardi, A.P., HaAs, J.S., Ascol, B.M., Bordignon, S.A.L., Poser, G. 2007. Germination and growth inhibitory effects of Hypericum myrianthum and H. polyanthemum extracts on Lactuca sativa L. Revista Brasileira de Farmacognosia 17: 44-48.

Fuentes-Ramírez, A., Pauchard, A., Cavieres, L., García, A. 2011. Survival and growth of Acacia dealbata vs. native trees across an invasion front in south-central Chile. Forest Ecology Management 261: 1003-1009.

Graña, E., Sotelo, T., Díaz-Tielas, C., Araniti, F., Krasuska, U., Bogatek, R., Reigosa, J.M., SÁnchez-Moreiras, A.M. 2013. Citral induces auxin and ethylene-mediated malformations and arrests cell division in Arabidopsis thaliana roots. Journal of Chemical Ecology 39: 271-282.

Hierro, J.L., Callaway, R.M. 2003. Allelopathy and exotic plant invasion. Plan Soil 256: 29-39.

Hirano, S., KIRA, T. 1965. Influence of autotoxic root exudation on the growth of higher plants grown at different densities. Journal of Biology Osaka City University 16: 27-44.

Hol, W.H.G., Vrieling, K., Van VeEn, J.A. 2003. Nutrients decrease pyrrolizidine alkaloid concentrations in Senecio jacobaea. New Phytologist 158: 175-181.

Hussain, M.I., González, L., Reigosa, M.J. 2011. Allelopathic potential of Acacia melanoxylon on the germination and root growth of native species. Weed Biology Management 11: $18-28$.

INDERJIT, S. 2005. Soil microorganisms: An important determinant of allelopathic activity. Plant Soil 274: 227-236.

InderJt, S., NiLsen, E.T. 2003. Bioassays and field studies for allelopathy in terrestrial plants: progress and problems. Critical Reviews Plant Sciences 22: 221-238.

Inderjt, S., Wardle, D.A., Karban, R., Callaway, R.M. 2011. The ecosystem and evolutionary contexts of allelopathy. Trends in Ecology \& Evolution 26: 655-662.

IndERJIT, S., WeInER, J. 2001. Plant allelochemical interference or soil chemical ecology? Perspectives Plant Ecology Evolution Systematics 4: 3-12.

Jasicka-Misiak, I., Piotr, P., Wieczorek, P.P., Kafarski, P. 2005. Crotonic acid as a bioactive factor in carrot seeds (Daucus carota L.). Phytochemistry 66: 1485-1491.

JiANG, G.Y., Li, Y.B., LiU, J.G. 2013. Autotoxicity potential of cotton tissues and root exudates and identification of its autotoxins. Allelopathy Journal 32: 279-287.

Karmegam, L.N., Kalpana, M., Prakash, M. 2014. Allelopathic Effect of aqueous root bark extract of Tamarindus indica L. and rhizosphere soil on germination and seedling growth of Oryza sativa. Journal of Current Microbiology and Applied Sciences 3: 505-514.

Kitazana, H., Asao, T., Ban, T., Pramanik, M.H.R., Hosoki, T. 2005. Autotoxicity of root exudates from strawberry in hydroponic culture. Journal of Horticultural Science and Biotechnology 80: 677-680.

Kong, C.H., Chen, L.C., Xu, X.H., Wang, P., Wang, S.L. 2008. Allelochemicals and activities in a replanted Chinese fir (Cunninghamia lanceolata (Lamb.) Hook.) tree ecosystem. Journal of Agricultural and Food Chemistry 56: 11734-11739.

Kraus, E., Voeten, M., Lambers, H. 2002. Allelopathic and autotoxic interactions in selected populations of Lolium perenne grown in monoculture and mixed culture. Functional Plant Biology 29: 1465-1473.

Lambers, H., Chapin, F.S.I., Pons, T.L. 2008. Plant physiological ecology. Springer, New York. 604 pp.

LiPinSKa, H., HaRkot, W. 2007. Allelopathic activity of grassland species. Allelopathy Journal 19: 3-36.

Liu, Y.H., Zeng, R.S., An, M., Mallik, A.U., Luo, S.M. 2008. Autotoxicity in agriculture and forestry. In: R.S. Zeng, A.U. Mallik \& S.M. Luo S.M. (eds.), Allelopathy in sustainable agriculture and forestry, pp. 283-301. Springer, New York.

Lorenzo, P., GonzÁlez, L., Reigosa, M.J. 2010a. The genus Acacia as invader: the characteristic case of Acacia dealbata Link in Europe. Annals of Forest Science 67: 101.

Lorenzo, P., Hussain, M.I., GonzALEZ, L. 2013. Role of allelopathy during invasion process by alien invasive plants in terrestrial ecosystems. In: Cheema, Z.A., Farooq, M., Wahid A. (eds.), Allelopathy: Current Trends and Future Applications, pp. 3-21. Springer, New York.

Lorenzo, P., Palomera-Pérez, A.E., Reigosa, M.J., González, L. 2011. Allelopathic interference of invasive Acacia dealbata Link on the physiological parameters of native understory species. Plant Ecology 212: 403-412.

Lorenzo, P., Pazos-Malvido, E., GonzÁlez, L., Reigosa, M.J. 2008. Allelopathic interference of invasive Acacia dealbata: physiological effects. Allelopathy Journal 22: 64-76.

Lorenzo, P., Pazos-Malvido, E., Reigosa, M.J., González, L. 2010b. Differential responses to allelopathic compounds released by the invasive Acacia dealbata Link (Mimosaceae) indicate stimulation of its own seed. Australian Journal of Botany 58: 546-553.

Lorenzo, P., Pazos-Malvido, E., Rubido-Bará, M., Reigosa, M.J., GonZÁLEZ, L. 2012. Invasion by the leguminous tree Acacia dealbata (Mimosaceae) reduces the native understorey plant species in different communities. Australian Journal of Botany 60: 669-675.

Mallik, A.U. 2002. On the question of paradigm in the science of allelopathy. In: M.J. Reigosa \& N. Pedro (eds.), Allelopathy: from molecules to ecosystems. Science, pp. 289-297. Publishers, Enfield.

Miller, D.A. 1996. Allelopathy in forage crop systems. Agronomy Journal 88: 854-859.

Murray, B.R. 1998. Density-dependent germination and the role of seed leachate. Australian Journal of Ecology 23: 411418.

Nilsson, M.C., Gallet, C., Wallstedt, A. 1998. Temporal variability of phenolics and batatasin-III in Empetrum hermaphroditum leaves over an eight-year period: interpretations of ecological function. Oikos 81: 6-16.

Olofsdotter, M. 1998. Allelopathy in rice. IRRI, Manila, 154 pp.

Pedrol, N., GonzÁlez, L., Reigosa, M.J. 2006. Allelopathy and abiotic stress. In: Reigosa, M.J., Pedrol, N., González, L. (eds.), Allelopathic: A physiological process with ecological implications, pp. 410. Springer, Netherlands.

Perry, L.G., Thelen, G.C., Ridenou, W.M., Weir, T.L., Callaway, 
R.M. 2005. Dual role for an allelochemical: (7)-catechin from Centaurea maculosa root exudates regulates conspecific seedling establishment. Journal of Ecology 93: 1126-1135.

Ren, X., He, X., Zhang, Z., Yan, Z., Jin, H., Li, X., Qin, B. 2015. Isolation, identification, and autotoxicity effect of allelochemicals from rhizosphere soils of flue-cured tobacco. Journal of Agricultural and Food Chemistry 63: $8975-8980$

Rice, E.L. 1984. Allelopathy. Academic Press, New York, 422 pp. Richardson, D.M., Carruthers, J., Hui, C., Impson, F.A.C., Miller, J.T., Robertson, M.P., Rouget, M., Leroux, J.J., WILSON, J.R.U. 2011. Human-mediated introductions of Australian acacias-a global experiment in biogeography. Diversity and Distributions 17: 771-787.

Rodríguez-Echeverría, S., Afonso, C., Correia, M., Lorenzo, P., RoILOA, S.R. 2013. The effect of soil legacy on competition and invasion by Acacia dealbata Link. Plant Ecology 214: $1139-1146$

SAmpietro, D.A. 2006. Sugarcane: soil sickness and autotoxicity. Allelopathy Journal 17: 33-41.

Sandjo, L.P., Rincheval, V., Ngadjutt, B.T. 2011. Cytotoxic effect of some pentacyclic triterpenes and hemisynthetic derivatives of stigmasterol. Chemistry of Natural Compounds 47: 731-734.

SantibÁÑEZ, F., Uribe, J.M. 1993. Atlas agroclimático de Chile. Facultad de Ciencias Agrarias y Forestales, Santiago de Chile, Chile. 99 pp.

Schenk, H.J., Callaway, R.M., Mahall, B.E. 1999. Spatial root segregation: Are plants territorial? Advances in Ecological Research 28: 145-180.

Schulz, M., Wieland, I. 1999. Variation in metabolism of BOA among species in various field communities-biochemical evidence for coevolutionary processes in plant communities? Chemoecology 9: 133-141.

Singh, H.P., Batish, D.R., Kohli, R.K. 2010. Autotoxicity: Concept, Organisms, and Ecological Significance. Critical Reviews in Plant Sciences 18: 757-772.

SinkKonen, A. 2007. Modelling the effect of autotoxicity on density-dependent phytotoxicity. Journal of Theoretical Biology 244: 218-227.

Souza, F.M., Gandolfi, S., Juliano, S.N., Ribeiro, R. 2010. Allelopathic potential of bark and leaves of Esenbeckia leiocarpa Engl. (Rutaceae). Acta Botanica Brasilica 24: 169-174.

Souza-Alonso, P., González, L., Cavaleiro, C. 2014. Ambient has become strained. Identification of Acacia dealbata Link volatiles interfering with germination and early growth of native species. Journal of Chemical Ecology 40: 1051-1061.

STATSOFt Inc. 2007. STATISTICA (data analysis software system), version 8.0. http://www.statsoft.com

WiLson, R.E., Rice, E.L. 1968. Allelopathy as expressed by Helianthus annuus and its role in old-field succession. Bulletin of the Torrey Botanical Club 95: 432-448.

Wu, H., Pratley, J., Lemerle, D., Haig, T. 2001. Allelopathy in wheat (Triticum aestivum). Annals of Applied Biology 139: $1-9$

Yan, X., You-Gen, W., Ying, C., Jun-Feng, Z., Xi-Qiang, S., GuoPeng, Z., Xin-Wen, H. 2015. Autotoxicity in Pogostemon cablin and their allelochemicals. Revista Brasileira de Farmacognosia 25: 117-123.

Ye, S.F., Yu, J.Q., Peng, Y.H., Zheng, J.H., Zou, L.Y. 2004. Incidence of Fusarium wilt in Cucumis sativus L. is promoted by cinnamic acid, an autotoxin in root exudates. Plant and Soil 263: 143-150.

XIE, M., Goh, T.N., Tang, X.Y. 2000. Data transformation for geometrically distributed quality characteristics. Quality and Reliability Engineering International 16: 9-15.

ZAR, J.H. 1996. Bioestatistical analysis. Prentice Hall, Englewood Cliffs. $663 \mathrm{pp}$

ZEN, R.Z. 2014. Allelopathy - The Solution is Indirect. Journal of Chemical Ecology 40: 515-516.

Zhang, S., Shi, F., Yang, W., Xian, Z., Kang, H., Duan, Z. 2015. Autotoxicity as a cause for natural regeneration failure in Nyssa yunnanensis and its implications for conservation. Israel Journal of Plant Sciences 62: 187-197.

Recibido: 25.07.2016

Aceptado: 03.10.2016 